\title{
FRANK H. H. ROBERTS, JR., 1897-1966
}

\section{Robert L. Stephenson}

$\mathrm{F}^{\mathrm{R}}$ RANK HAROLD HANNA ROBERTS died of a heart attack at Sibley Memorial Hospital in Washington, D.C., on February 23, 1966 , at the age of sixty-eight years, six months, and twelve days. His ashes were interred at Arlington National Cemetery in a simple, military, graveside service that seemed most appropriate for a man of his modest and unassuming nature who nevertheless has left such a masterful imprint on his lifelong profession. James Bryant Conant once said, "Each honest calling, each walk of life, has its own elite, its own aristocracy based on excellence of performance." If American archaeology has ever had such elite, such aristocracy, Frank Roberts was surely foremost among them. Universally respected and admired by all who knew him, he was one of the most influential and most honored of American archaeologists.

He was born on August 11, 1897, in Centerburg, Ohio, to Frank Hunt Hurd Roberts and Lou Ella (Hanna) Roberts. The family moved in 1900 to Laramie, Wyoming, where his father taught history and civics. In 1903 the senior Dr. Roberts joined the faculty of the University of Denver and the family lived in Denver for seven years where the second son, Henry, was born in 1904. In 1910, his father was named President of the Las Vegas Normal University in Las Vegas, New Mexico, and young Frank went to high school there and took his first year of college at that university.

In 1916, he went to the University of Denver where he was graduated in history and English in 1919, having interrupted his education to serve his country in the Army from August to December, of 1918. At the University he was elected to Beta Theta Pi social fraternity, Sigma Delta Chi national journalism fraternity, and to Phi Beta Kappa. Though his family had moved to El Paso, Texas, in 1915, he returned to Las Vegas upon graduation and there became a reporter and City Editor on the newspaper, The Las Vegas Daily Optic. In September, 1920, he returned to the University of Denver and the following June received the Master of Arts degree in political science.

It was at this time, after having studied under Renaud, that he became seriously interested in anthropology and began working with J. A.
Jeancon and E. B. Renaud. He spent the next three years teaching courses in Spanish and anthropology with Dr. Renaud at the University of Denver. Concurrently, during those years, he was Assistant Curator of Archaeology under J. A. Jeancon at the State Historical and Natural History Society of Colorado - the State Museum. It was in this latter position that he did his first archaeological field work. In the summer of 1921, he began field work in the Piedra-Pagosa region of the upper San Juan River Basin in southwestern Colorado, as assistant to Jeancon. The results were published by Jeancon the next year under the editorship of Frank H. H. Roberts. The next three summers were spent in a continuation of the investigations along the Piedra River as Assistant Director and Director of the expeditions. He published the results jointly with Jeancon and, also, under his name alone in the first several issues of The Colorado Magazine.

In the fall of 1924, he left Denver to continue academic work at Harvard University where he received the Hemenway Fellowship for 1924-25 and was an assistant in anthropology at Harvard during the 1925-26 year. While at Harvard he was elected to the Society of the Sigma $\mathrm{Xi}$. During these two years his anthropological horizons were greatly broadened under the influence of such eminent teachers as Alfred $M$. Tozzer, Roland B. Dixon, Samuel J. Guernsey, and Earnest A. Hooton. Alfred V. Kidder was Curator of North American Archaeology at the Peabody Museum, and fellow students included Oliver La Farge, Bert Cosgrove, Harry Shapiro, George Vaillant, and Frans Blom.

$\mathrm{He}$ joined the National Geographic Society expedition to Pueblo Bonito under the direction of Neil M. Judd in the summer of 1926, and this provided the material for his doctoral dissertation: "The Ceramic Sequence in the Chaco Canyon, New Mexico, and its Relation to the Cultures of the San Juan Basin." Upon his return from Chaco Canyon, he joined the staff of the Bureau of American Ethnology at the Smithsonian Institution on November 1, 1926. His thesis was accepted at Harvard and the degree of Doctor of Philosophy was granted him in June, 1927. 


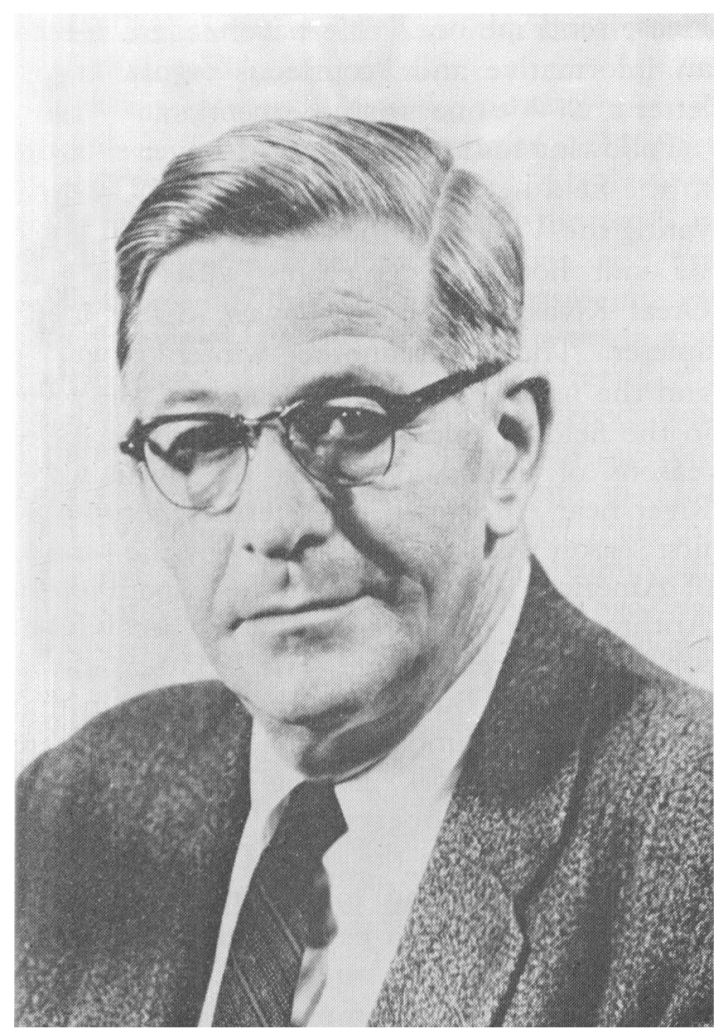

Dr, Frank H. H. Roberts, JR. (August 1961)

On May 6, 1927, he was married to Linda Butchart from Denver. Linda had been a freshman student in English Literature when they first met at the University of Denver some four years before and had taken some of his courses in anthropology. They spent their honeymoon in Chaco Canyon excavating Shabik'eshchee Village, and Linda was to spend her next 15 summers in her husband's field camps, cataloguing artifacts and repairing and sketching pottery. Theirs was a happy marriage, and they were a very close and devoted couple for almost 39 years. Linda became an accomplished artist and did many of the illustrations for Dr. Roberts' publications. They had no children.

When Dr. Roberts came to the Bureau of American Ethnology in the fall of 1926, he joined such eminent scholars as John P. Harrington, John R. Swanton, J. N. B. Hewitt, Francis LaFleche, Truman Michelson, and Jesse Walter Fewkes. He became closely associated, too, with the U.S. National Museum anthropologists, Walter Hough, Neil M. Judd, Herbert W. Krieger, Henry B. Collins, Frances
Densmore, and Ales Hrdlička. Dr. Roberts was to devote more than 37 years to the Bureau of American Ethnology. He was staff archaeologist from 1926 to 1944, first under Jesse Walter Fewkes and, after August, 1928, under Mathew W. Stirling. He became Assistant Chief in 1944 and Associate Director in 1947. Upon Dr. Stirling's retirement on December 31, 1957, he became Director, in which capacity he served until his retirement on June 5, 1964. $\mathrm{He}$ had served the Smithsonian under five Secretaries: Charles Doolittle Walcott, Charles Greely Abbott, Alexander Wetmore, Leonard Carmichael, and Sidney Dillon Ripley.

His first few months in the Bureau were spent in bringing the report of the Chaco Canyon pottery to completion, but in May, 1927, he was again on his way to the field. He briefly investigated a series of caves in the vicinity of El Paso, Texas, and then began the excavation of Shabik'eshchee Village in Chaco Canyon, New Mexico. Near the end of the season he made a two weeks' reconnaissance along Montezuma Creek in southeastern Utah to locate additional Basketmaker sites.

At the end of August he participated in the first Pecos Conference at Pecos Pueblo, New Mexico, where Dr. A. V. Kidder was excavating for the Carnegie Institution of Washington. At this conference Dr. Roberts took a major role in drafting a new outline of culture sequences for southwestern archaeology. This was the now well-known "Pecos Classification" that established the numbered sequences of Basketmaker-Pueblo cultures.

Before returning to Washington, he spent a week visiting the excavations of the Colorado Museum of Natural History near the town of Folsom, New Mexico, where projectile points of a specialized, fluted style were being found in association with the bones of an extinct form of bison. The evidence was so convincing and the implications so significant that he called Dr. Kidder to come from Pecos to see the material in place. This was the beginning of the important study of the Folsom culture in American archaeology and set the stage for Dr. Roberts' long devotion to the problems of Early Man in the New World.

During the winter months he completed the reports of the work in the vicinity of El Paso and at Shabik'eshchee. In February, he made a brief trip to Melbourne, Florida, to examine a site that appeared to be related to the then 
controversial finds of early man materials near Vero Beach, Florida. In May, 1928, he returned to the upper San Juan River area to excavate a Pueblo I period site on the Piedra River near Arboles, Colorado. Here he defined a threestage development of house types culminating in a prototype of the unit structure that foreshadowed the Pueblo II period houses. At the end of the season he again visited the excavations at the Folsom site and finished the season with a horseback reconnaissance through the Governador and Frances canyons of New Mexico. Again the winter months were spent in writing up the summer's work.

The summer of 1929 was spent excavating at the Long $\mathrm{H}$ Ranch in eastern Arizona, 45 miles west of Zuñi Pueblo. In this Basketmaker III-Pueblo 1 site he demonstrated the transition from Late Basketmaker into Pueblo culture, a transition of especial significance in strengthening the then new "Pecos Classification." Of it he said in a note to The Teocentli for December, 1929: "I dug a 45 room and 4 kiva pueblo of the Classic Period and finally under its north end found the remains of a fairly well-preserved pit house. With this bit of evidence as to the priority of the pit houses, I felt that the time and energy spent in cleaning out the pueblo had not been wasted." His real interest was in the earlier structures and in the origins and sequences of Southwestern cultures. The later, more spectacular, structures were merely obstacles to be overcome in getting at the basic cultural problems. At the end of the season he again participated in the Pecos Conference.

That winter was typical of his winters at the Bureau during this period and demonstrates the enormous productivity of the man. He began and completed a 600-page manuscript, including the drawing of 71 maps and figures to illustrate it, and corrected both galley and page proof on a manuscript of similar size prepared the previous winter. In addition he maintained the usual flow of correspondence connected with the Bureau, ranging from professional letters and requests to inquiries from school children asking him to "please send me all you know about the Indians." It was perhaps about this time that he received a letter from such a youngster that he always enjoyed relating. It was addressed to him at the Bureau and said: "Dear Bureau: My teacher says if I write you a polite letter I will get a courteous reply.
Please send me one." He never failed to send an informative and "courteous" reply to any letter and this one was no exception.

Following his annual stop in Denver en route to the field he spent the summer of 1930 excavating the Village of the Great Kivas, a Pueblo III unit house of 84 rooms with associated Great Kivas, one of which was 78 feet in diameter. There was another winter of writing and the usual Bureau duties, and he was again in the field by mid-May of 1931 to begin three seasons of excavation along the Whitewater River near Allentown in eastern Arizona. The first season was sponsored jointly by the Bureau of American Ethnology and the Laboratory of Anthropology in Santa Fe and the second season by the Bureau alone. The 1933 season was to have been a Bureau project, too, but in that depression year funds were inadequate for more than a month's work. During July and August, therefore, Dr. Roberts took leave from the Smithsonian to join the staff of the Laboratory of Anthropology and to continue the Allentown excavations as a part of the field-training program for graduate students. The three seasons of work in this complex of early Pueblo I pit houses and Pueblo II unit houses were successfully completed in September of 1933. This was his last major excavation in the agricultural sites of the southwest, and other assignments, duties, and interests were beginning to encroach upon his time.

Dr. Roberts was detailed as consulting archaeologist to the Carnegie Institution of Washington in February, 1932, and spent three weeks advising on the excavations at Chichen Itza and Uxmal in Yucatan and visited George Vaillant's excavations at San Juan Teotihuacán in Mexico for a week. Also in 1932 his editorial talents were again called into service and he became Associate Editor of the American Anthropologist, a position he was to occupy for 12 years.

In December, 1933, he began his only excavations in southeastern archaeology. Under the auspices of the Civil Works Administration he spent $31 / 2$ months excavating seven prehistoric mounds on the Civil War battlefield at Shiloh National Military Park in Tennessee. It had been at Shiloh that Major J. W. Powell had lost his arm during the Civil War, and Dr. Roberts was often kidded that the real purpose 
of the excavations was not to dig the mounds but to recover the Major's arm.

The summer of 1934 was a turning point in his career. It was the first summer in 14 years that he did not spend in the field. He devoted the time to preparing reports on the work in the Whitewater District of Arizona and the excavations at Shiloh, but his basic interest was changing. His concern with the origin and development of the sedentary cultures of the southwest had led him to an even deeper concern for the earlier origins of man on the continent. His visits to the Folsom site in 1927 and 1928 had shown him clearly that the Hrdlička point of view, of man's coming to the continent but 3,000 or 4,000 years ago, was no longer tenable. He set about tracking down all available evidence of Early Man and became involved in voluminous correspondence on the subject. His interest became generally known over the country, and collectors began sending him information and specimens to be examined. One of these collectors was Major Roy G. Coffin who, with his brother and nephew, had found Folsom points on the William Lindenmeier ranch near Ft. Collins in northern Colorado. In the fall of 1934 , Dr. Roberts visited the site and spent six weeks testing it and exploring the surrounding area. This initial, brief season clearly showed the Lindenmeier site to be a large campsite of Folsom man with fluted points associated with bones of an extinct form of bison. Plans were made for major excavations to begin the next summer.

The second season at Lindenmeier began in May, 1935, with the start of extensive excavations that were to continue each summer through 1940. Each season, in conjunction with the three or four months spent digging at the main site, he also investigated other locations of reported early man materials. In 1935, several sites in north-central Colorado and southern Wyoming were examined. In 1936, en route to Lindenmeier, he visited several encouraging looking sites in Iowa, and at the end of the season he excavated briefly at the Powars site near Kersey, Colorado. The latter was a small Folsom campsite with artifacts similar to those at Lindenmeier but with few faunal remains. At the start of the 1937 season, he sampled a site near Kingman, Arizona, and, following the season, visited several sites near North Platte, Nebraska. At the end of the 1938 season he investigated a number of localities in south- western Nebraska, northeastern Wyoming, and near Mortlach, Saskatchewan, where local collectors had reported early man discoveries. Other sites were briefly examined in conjunction with the seasons of 1939 and 1940 at Lindenmeier. Each of these added its bit to the accumulating knowledge of Early Man in America, and the Lindenmeier site itself had proved to be a veritable fountain of information. Dr. Roberts had become the foremost scholar of the Paleo-Indian and was invited to participate in symposia to discuss the subject at meetings in various parts of the country.

Other matters of consequence were also claiming his attention during those years. In 1934 there was enthusiasm for a national organization of American archaeologists, and Dr. Roberts, Dr. Kidder, and Dr. A. L. Kroeber were asked to form a committee to prepare a constitution and by-laws as a basis for such a national society. With this foundation the Society for American Archaeology was formed in December, 1934, with its journal, American Antiquity, appearing for the first time in July, 1935. Dr. Roberts was the Assistant Editor for Early Man for that first issue and continued in that post until 1950. Then, in 1935 he was appointed by the American Anthropological Association as its representative on the $\mathrm{Na}$ tional Research Council. He held this appointment from 1935 to 1937, again from 1939 to 1941, and from 1947 to 1949, and he served as Vice Chairman of the Division of Anthropology and Psychology of the National Research Council in 1946. He was also elected President of the Anthropological Society of Washington for the year 1936-37.

Gila Pueblo at Globe, Arizona, invited him, in the fall of 1935 , to advise them on the work at the large Hohokam site of Snaketown in central Arizona. It is of interest to note, in retrospect, that he had long been a leader in the development of Southwestern archaeology, and his advice was constantly sought in that field; yet by 1934 his active field work in the sedentary cultures of the Southwest was at an end. This did not, however, end his interest nor his active participation in Southwestern archaeology. He kept in constant touch with all of the new developments, and articles on the subject continued to flow from his pen for another 30 years. In fact, his very last undertaking before his death was a review of John C. McGregor's 1965 revision of Southwestern Ar- 
chaeology. He was not able to complete this review.

The Robertses sailed for Cairo, Egypt, in February, 1937, where Dr. Roberts served as one of two American experts at the International Conference of Archaeologists, held March 9 to 17, under the auspices of the Committee for Intellectual Cooperation of the League of Nations. There he presented a significant paper on "The Material Organization of an Archaeological Mission," discussing the choice of a field staff, securing equipment, establishing a field headquarters, and the general administration of such a project. These were all matters that were to become especially significant for him almost a decade later in organizing the nation-wide River Basin Surveys program. At the close of the conference they visited many archaeological sites and museums in Egypt and the Mediterranean, returning to Washington at the end of April. During the winters of 1937-38 and 1938-39, he completely revised the Whitewater District manuscript and sent the two volumes to the printer, thus completing all of his field reports up to the beginning of the Lindenmeier work, and progress reports were being published annually on that excavation.

In March, 1939, Secretary of State Cordell Hull appointed Dr. Roberts to represent the United States on the International Commission for Historic Sites and Monuments, in which capacity he served for four years. From 1939 to 1941 , he was technical editor for the Smithsonian educational radio program series "The World is Yours" preparing scripts for such diverse subjects as Carthage, Zebulon M. Pike, Babylon, and Pompeii. He took leave of absence during the month of August, 1940, to teach at the University of New Mexico's Chaco Canyon field school, at the end of which he visited Rampart Cave near Boulder City, Nevada, to advise on plans for future excavation of that potential Paleo-Indian site with its abundance of sloth bones and other extinct fauna. The winter of 1940-41 was largely devoted to the preparation of a comprehensive report on the seven seasons at Lindenmeier and of several short articles for various journals. In May, he briefly excavated at the Mons site near the Peaks of Otter in western Virginia, but the Paleo-Indian aspect of the site failed to materialize.

Early in June, 1941, he began the excavation of the San Jon site in eastern New Mexico, another early man site with associated fauna of extinct species. At the end of that season he again taught at the Chaco Canyon field school and couldn't resist the temptation to excavate, with Paul Reiter and William Mulloy, a small pueblo site nearby.

As a result of the events of December 7, 1941, his organizational abilities were again called upon but in quite a different way than before. He organized the air-raid protection groups for the Smithsonian buildings and was Building Warden for the duration of the war. Throughout the war years his time was devoted mainly to war-connected activities such as personnel utilization, Civil Service matters, preparations for evacuation of the National collections, anti-subversion safety measures, personnel security clearance, and providing cultural background material for the armed forces. $\mathrm{He}$ was a member of numerous boards and commissions in connection with these activities. As a part of his work on the Ethnogeographic Board he prepared several survival articles for the armed forces, culminating in two manuals for the Office of Naval Intelligence and the Army Air Force, both entitled "Survival on Land and Sea," and a War Background Study on "Egypt and the Suez Canal." He represented the Smithsonian on the Civil Service Efficiency Rating Review Board and attended that board's annual institutes for several years. He was designated Acting Chief of the Bureau of American Ethnology on April 1, 1943, to act in the absence of the Chief, and in September, 1944, he was appointed Assistant Chief. In 1944, Dr. Roberts was elected Vice-President of the American Anthropological Association.

Despite all of these activities during the war he still found time for archaeology and even for some field work. In June, 1942, he and his brother, Henry, spent six weeks excavating at the Agate Basin site, near Newcastle, Wyoming, where bison bones and a specialized style of unfluted Paleo-Indian points were found associated. In July, 1943, he examined a deep burial that appeared to be in a Pleistocene deposit on the Clear Fork of the Brazos River near Abilene, Texas. This must have been an exciting trip for him because throughout the years at Lindenmeier, he had kept hoping to find the bones of Folsom Man. This was always a disappointment to him, and in one issue of The Teocentli he said ". . . but we still couldn't 
find old man Folsom himself. When it comes to hiding out, he truly is the Vanishing American." Archaeological reports were not neglected during the war years either. He completed the San Jon report and the Abilene burial report and published several briefer articles on the Paleo-Indian and on Southwestern archaeology, as well as continuing work on the major report of the Lindenmeier site.

In 1945 another turning point came in Dr. Roberts' career, one that was destined to virtually terminate his personal field work but to bring him into intimate contact with all phases of archaeology over the entire nation. He had devoted a dozen years to the Southwest, from 1921 to 1933, and another decade, from 1934 to 1944 , to the study of the Paleo-Indian. Now, while maintaining active interest in both these fields he was to devote his major effort for the next 18 years to the administration of archaeology. As he put it, "I must now content myself with doing my archaeology by proxy."

This period began late in 1944 with the rapid, post-war acceleration of the nation-wide water control and reservoir construction program. $\mathrm{He}$ quickly recognized the threat to archaeological sites along the rivers and began making plans for the Bureau of American Ethnology to salvage the archaeological materials before these sites were flooded. At the same time other archaeologists, particularly Dr. J. O. Brew of Harvard, and Fred Johnson of Andover, also recognized the threat and began to make salvage plans. Discussions with the officials of the National Park Service and the Smithsonian Institution resulted in a co-operative plan for an Inter-Agency Archaeological Salvage Program that brought the Smithsonian Institution into a most successful partnership with the $\mathrm{Na}$ tional Park Service. By official agreement, the National Park Service was to provide the federally appropriated funds for the work, and the Smithsonian was to assume the responsibility for the actual research under Dr. Roberts' direction. An independent, advisory group The Committee for the Recovery of Archaeological Remains - sponsored by the American Council of Learned Societies, the Society for American Archaeology, and the American Anthropological Association, was formed to aid both agencies where and when needed. Dr. Roberts was designated liaison officer between the Smithsonian and this committee in March, 1945, and the program to be known as the
River Basin Surveys was begun with Dr. Roberts as its director. Field work started the following July.

Many other federal, state, and local agencies were brought into the program, especially the reservoir construction agencies and the universities, historical societies, and museums in the areas of the reservoirs. Field offices were established in Lincoln, Nebraska, in July, 1946, and the following spring, in Austin, Texas, and Eugene, Oregon, and smaller units began operating in California and the southeastern states. The River Basin Surveys became the largest and most successful single archaeological effort ever undertaken, and this success was due in very large measure to the selfless and dedicated efforts of a handful of individuals, foremost among whom was Dr. Roberts. During his administration of the River Basin Surveys, Smithsonian crews examined and recorded 5,040 archaeological sites in 269 reservoir areas in 29 states and excavated 526 of these sites, resulting in 439 published reports of the findings. These sites varied from early Paleo-Indian camps, through nearly all of the temporal and cultural complexes, to the village remains left by the historic Indians of the nineteenth and twentieth centuries, as well as the frontier trading posts and military establishments of EuroAmerican origin. In addition to this, the combined salvage efforts of the state universities and historical societies working as cooperators in the River Basin Surveys program all over the nation were of a similar scale.

During the early years of the River Basin Surveys, Dr. Roberts' major efforts were devoted to the assembling of the details of where and when the reservoirs were to be built and planning the salvage work. His was not an armchair participation in any aspect of the program. He personally developed the procedures by which the field offices were to operate, secured equipment and supplies for them, did the major staffing, and developed the budgets. $\mathrm{He}$ visited the multitudes of reservoir areas to see at firsthand the archaeological potentials involved, and he outlined the procedures for the field work. With few exceptions, he visited every reservoir and every major excavation that the Smithsonian crews and many of the cooperators' crews were working on during his annual trips of inspection. Yet never were his field directors or his staff archaeologists made to feel that he was imposing his procedures or 
regulations upon them. There was always opportunity for flexibility, and the judgment of the man in the field was always respected. He was the kind of person who could direct and coordinate the work of many other archaeologists and make them all feel that they were doing all the work themselves. This was accomplished largely by his slow, easy-going manner and his deep concern for the feelings and viewpoints of other people, as well as by his intimate knowledge of the problems of American archaeology and how to cope with them. His was a gigantic task of organization and administration and demonstrated, as nothing else could have, his talent for combining the knowledge gained by his long and varied experience in archaeology with an unequalled skill and facility for putting together a nation-wide research program and making it function successfully.

The River Basin Surveys was clearly his chief interest for the rest of his life because of his sincere belief in its importance to the American heritage. Yet he had to make time for other things, too. Dr. Stirling was in the field much of this time and, as Associate Director of the Bureau of American Ethnology, the full responsibility of running the Bureau fell upon him when Dr. Stirling was gone. He continued to serve as the Smithsonian representative on the Civil Service Efficiency Rating Review Board, the Committee on Personnel Utilization, the Internal Security Board, and other boards and committees of the Institution. Each year he annotated several books for the United States Quarterly Book List of the Library of Congress and was consultant on anthropology for several encyclopedias. He continued to write and publish numerous articles on the River Basin Surveys, the Southwest, and the Paleo-Indian, and in 1946 he wrote a very significant article on "One Hundred Years of Smithsonian Anthropology." In May, 1946, he represented the Smithsonian at the Sesquicentennial Celebration at the University of North Carolina and, in April, 1947, at an organizational meeting of the National Council for Historic Sites and Buildings, on which council he served for several years.

Many honors and distinguished positions were beginning to be his during these years. In 1947-48, he was appointed to the Committee on Appointments for the Peabody Museum of American Archaeology and Ethnology and became a member of the Visiting Committee of the Board of Overseers of Harvard College, appointments he was to have repeatedly for a decade and a half. He was elected to membership in the Cosmos Club of Washington in January, 1948, and in 1949 was elected President of the Washington Academy of Sciences. In May, 1950, he was elected President of the Society for American Archaeology which he had helped to found almost 15 years before. That Society also selected him to receive the Viking Fund Medal and Award for 1951; he was the sixth person ever to be so honored. He was elected Vice President of the American Association for the Advancement of Science and was Chairman of its Section " $\mathrm{H}$ " in 1952. At the request of UNESCO that year, he wrote a major article on "Earliest Man in America" for the International Commission for a Scientific and Cultural History of Mankind. In May, 1952, Dr. Roberts was honored with a special Alumni Award from the University of Denver "For distinguished service in the field of American archaeology."

A major part of his effort was gradually being diverted, now, to the review and editing of the numerous manuscripts that were beginning to come in from the River Basin Surveys archaeologists. He was appointed Scientific Editor for these papers in the Bureau of American Ethnology Bulletin series in 1953, and again his editorial training served him to advantage. He rather enjoyed this, too, since in these manuscripts he was seeing the real results of all the work that had gone into the salvage program.

In 1952, he began a seven year term as Chairman of the Personnel Security Board of the Institution and in 1955 was appointed Employment Policy Officer for four years. At the end of 1957, he became Director of the Bureau of American Ethnology upon Dr. Stirling's retirement. Occasionally, when the Secretary and the Assistant Secretaries were gone, Dr. Roberts was designated Acting Secretary of the Smithsonian Institution.

The National Geographic Society invited him to become a consultant to its Research Committee in September, 1958, for the archaeological project that it was jointly sponsoring with the National Park Service at Weatherill Mesa in Mesa Verde National Park. He served on the Advisory Board for this project until his death and was its chairman in 1960 and 1961. He continued to represent the Institution at numer- 
ous national and international meetings, participating in symposia and presenting papers at most of them, and he was elected President of the District of Columbia Chapter of the Society of the Sigma Xi for the 1957-59 term.

The University of New Mexico awarded Dr. Roberts an honorary Doctor of Laws degree in ceremonies at Commencement in Albuquerque in 1957, and the University of Colorado awarded him an honorary Doctor of Laws degree in Boulder in 1959.

Despite his continuing administrative load, he always wanted to get back to the field himself, which he had not been able to do since the River Basin Surveys began. Especially he wanted to learn more of the Paleo-Indian site at Agate Basin, Wyoming, where he and his brother Henry had worked in 1942 . The opportunity came in 1961 when the National Geographic Society provided funds for a season of excavation there. Following a trip to Oklahoma in April, he went to the site and arranged permission to dig. Early in June he returned to Agate Basin with Dr. William M. Bass of the University of Kansas as his field foreman and a crew of student laborers. After a week at the dig he had to return to Washington, leaving Bass in charge of the work, and, while there, completed the report of the 1942 excavations at Agate Basin. He returned to the field in July, made the usual inspection trip around the Missouri Basin field camps, and was back at Agate Basin for the last two weeks of the season's work. He had satisfied his wish for one last season in the field and had brought the Agate Basin excavations to a satisfactory conclusion. Upon returning to Washington he was invited to represent the United States at a "Conference on the Origin and Antiquity of Man in the New World" in São Paulo, Brazil. Late in August, Dr. and Mrs. Roberts flew to São Paulo where he presented three papers and was elected Vice President of the Conference. In September, he visited the Weatherill Mesa Project in his capacity of Chairman of the Advisory Board, and in November he participated in the Plains Conference in Lawton, Oklahoma. During the winter he was on the National Park Service Advisory Board for its Okmulgee Project near Macon, Georgia, and made two trips to that project. Except for the field work, this year had been fairly typical of the past dozen or more years. This was an exhausting pace, and it was beginning to take its toll of Dr.
Roberts' health, though he himself seemed unaware of it or unwilling to admit it.

At the Commencement ceremonies in June, 1962, the University of Denver conferred upon him his third honorary Doctor of Laws degree. While in Denver for this occasion he suffered a mild heart attack. He seemed to make a quick recovery and was soon back at his desk but his activities were greatly curtailed. He did not make the inspection trip around the Missouri Basin that year nor the next, the first he had missed since the Salvage Program began in 1946.

On October 15, 1963, Dr. Roberts was stricken with a severe heart attack and was in the hospital for six weeks. He made a slow but steady recovery during the winter and spring, but on his doctor's orders he retired from the Smithsonian Institution on June 5, 1964. That Thanksgiving, at the Plains Conference in Lincoln, Nebraska, he was presented, in absentia, a bronze plaque "In appreciation of long service to Plains Archaeology."

He fully intended to complete his only two unfinished manuscripts - on Lindenmeier and Agate Basin - during his retirement. He even prepared a room at home where he could work on them, but he was not able to begin. His final illness was brief, and he was in the hospital but two weeks when his third, and fatal, heart attack came.

Frank H. H. Roberts, Jr., scholar, anthropologist, archaeologist, administrator, editor, humanist, and great friend is gone, but his kindness to people, his warm, jovial, easy-going manner, and his devotion to fair play and straightforward dealings will long be an inspiration to all who knew him. His work will remain landmarks for generations of archaeologists.

BIBLIOGRAPHY OF FRANK H. H. ROBERTS, JR.

CompILED BY

Robert L. Stephenson and G. Hubert Smith

$$
1922
$$

(Editor) Archaeological Research in the Northeastern San Juan Basin of Colorado during the Summer of 1921, by Jean Allard Jeancon. The State Historical and Natural History Society of Colorado and the University of Denver, Denver. 31 pp.

Report on the Work of the 1922 Season in the Piedra Parada Archaeological Field. University of Denver Bulletin, Vol. 23, No. 9. Denver. 12 pp. 
1923

(with J. A. Jeancon) Further Archaeological Research in the Northeastern San Juan Basin of Colorado, during the Summer of 1922. The Colorado Magazine, Vol. 1, No. 1, pp. 10-36. The State Historical and Natural History Society of Colorado, Denver.

1924

(with J. A. Jeancon) Further Archaeological Research in the Northeastern San Juan Basin of Colorado, during the Summer of 1922. The Colorado Magazine, Vol. 1, No. 2, pp. 65-70. The State Historical and Natural History Society of Colorado, Denver.

Excavation Work in the Pagosa-Piedra Field during the Season of 1922. The Colorado Magazine, Vol. 1, No. 3, pp. 101-18. The State Historical and Natural History Society of Colorado, Denver.

Excavation Work in the Pagosa-Piedra Field during the Season of 1922. The Colorado Magazine, Vol. 1, No. 4, pp. 163-73. The State Historical and Natural History Society of Colorado, Denver.

The Pre-Columbian Cultures, House Types and Their Distributions in the State of Colorado. Unpublished manuscript on file in the Department of Anthropology, University of Denver, Denver.

Report on Archeological Reconnaissance in Southwestern Colorado in the Summer of 1923. The Colorado Magazine, Vol. 2, No. 2, pp. 1-80. The State Historical and Natural History Society of Colorado, Denver.

\section{7}

The Ceramic Sequence in the Chaco Canyon, New Mexico, and Its Relation to the Cultures of the San Juan Basin. Unpublished doctoral dissertation, Harvard University. Cambridge.

\section{8}

A Late Basketmaker Village of the Southwest. Explorations and Field-Work of the Smithsonian Institution in 1927, pp. 165-72. Washington.

Shabik'eshchee Village, a Late Basket Maker Site in the Chaco Canyon, New Mexico. Bureau of American Ethnology, Bulletin 92. Washington. viii +164 pp.

Recent Archaeological Developments in the Vicinity of El Paso, Texas. Smithsonian Miscellaneous Collections, Vol. 81, No. 7. Washington. 14 pp.

Certain Early Pueblo Villages in Southwestern Colorado. Explorations and Field-Work of the Smithsonian Institution in 1928, pp. 161-8. Washington.

\section{0}

Early Pueblo Ruins in the Piedra District, Southwestern Colorado. Bureau of American Ethnology, Bulletin 96. Washington, ix $+190 \mathrm{pp}$.

Two Ancient Indian Cultures in Eastern Arizona. Explorations and Field-Work of the Smithsonian Institution in 1929, pp. 187-94. Washington.

\section{1}

A Prehistoric Village on the Zuñi Reservation, New Mexico. Explorations and Field-Work of the Smithsonian Institution in 1930, pp. 177-86. Washington.
The Ruins of Kiatuthlanna, Eastern Arizona. Bureau of American Ethnology, Bulletin 100. Washington. viii + 195 pp.

The Ceramic Sequence in the Chaco Canyon, New Mexico, and Its Relation to the Cultures of the San Juan Basin. In Summaries of Theses Accepted in Partial Fulfillment of the Requirements for the Degree of Doctor of Philosophy, pp. 9-11, Harvard University Graduate School of Arts and Sciences. Abstract. Harvard Press, Cambridge.

(with John R. Swanton) Jesse Walter Fewkes. Annual Report of the Smithsonian Institution for 1930, pp. 609-16. Washington.

\section{2}

An Important Archeological Site in Eastern Arizona. Explorations and Field-Work of the Smithsonian Institution in 1931, pp. 141-50. Washington.

The Village of the Great Kivas on the Zuñi Reservation, New Mexico. Bureau of American Ethnology, Bulletin 111. Washington. ix $+197 \mathrm{pp}$.

Archeological Investigations Bring to Light Dwelling Built in 797 A.D. The Ohio Alumnus, Vol. 10, No. 2, pp. 4-5. Ohio University, Athens.

\section{3}

Some Early Pueblo Remains in Eastern Arizona. Explorations and Field-Work of the Smithsonian Institu. tion in 1932, pp. 65-8. Washington.

\section{4}

An Arizona Village of a Thousand Years Ago. Explora. tions and Field-Work of the Smithsonian Institution in 1933, pp. 41-3. Washington.

True Folsom Points. Literary Digest, Vol. 118, No. 4 , July 18, p. 18. New York.

Archeologenesis. The Biologist, Vol. 16, No. 1, pp. 14 19. Denver.

A Folsom Camp Site and Workshop. Explorations and Field-Work of the Smithsonian Institution in 1934, pp. 61-4. Washington.

Indian Mounds on Shiloh Battlefield. Explorations and Field-Work of the Smithsonian Institution in 1934, pp. 65-8. Washington.

A Folsom Complex: Preliminary Report on the Investigations at the Lindenmeier Site in Northern Colorado. Smithsonian Miscellaneous Collections, Vol. 94, No. 4. Washington. $53 \mathrm{pp}$.

Folsom Complex: Preliminary Report on the Investigations at the Lindenmeier Site in Northern Colorado (a summary). Nature, Vol. 136, Oct. 5, pp. 535-8. London.

A Survey of Southwestern Archeology. American Anthropologist, Vol. 37, No. 1, pp. 1-35. Menasha.

\section{6}

A Survey of Southwestern Archeology. Annual Report of the Smithsonian Institution for 1935, pp. 507-33. Washington.

Problems in American Archeology. Southwestern Lore, Vol. 1, No. 4, pp. 8-11. Gunnison. 
References. (The Present Status of Knowledge Relating to the Antiquity of Man in America). Report of the XVI International Geological Congress, Washington 1933, pp. 1318-23. Washington.

Additional Information on the Folsom Complex: Report on the Second Season's Investigations at the Lindenmeier Site in Northern Colorado. Smithsonian Miscellaneous Collections, Vol, 95, No. 10. Washington. $38 \mathrm{pp}$.

Recent Discoveries of the Material Culture of Folsom Man. The American Naturalist, Vol. 70, pp. 337-45. Lancaster.

Further Investigations at a Folsom Campsite in Northern Colorado. Explorations and Field-Work of the Smithsonian Institution in 1935, pp. 69-74. Washington.

Early Man in America. Indians at Work, Vol. 4, No. 9, pp. 11-14. Washington.

The Significance of Folsom Points East of the Mississippi. Archeological Society of Delaware, Bulletin, Vol. 2, No. 4. Dover. 34 pp.

The Material Organization of an Archeological Mission. Unpublished paper presented at the International Conference of Archaeologists, Cairo, Egypt, under the auspices of the Institute for Intellectual Cooperation of the League of Nations.

1937

New Developments in the Problem of the Folsom Complex. Explorations and Field-Work of the Smithsonian Institution in 1936, pp. 69-74. Washington.

The Material Culture of Folsom Man as Revealed at the Lindenmeier Site. Southwestern Lore, Vol. 2, No. 4, pp. 67-73. Gunnison.

New World Man. American Antiquity, Vol. 2, No. 3, pp. 172-7. Menasha.

The Folsom Problem in American Archaeology. In Early Man as Depicted by Leading Authorities at the International Symposium, The Academy of Natural Sciences, Philadelphia, March, 1937, edited by George Grant McCurdy, pp. 153-62. J. B. Lippincott Co., Philadelphia and New York.

In the Empire of the Aztecs. National Geographic Magazine, Vol. 71, No. 6, pp. 724-50. Washington.

Archaeology in the Southwest. American Antiquity, Vol. 3, No. 1, pp. 3-33. Menasha.

\section{8}

The Lindenmeier Site in Northern Colorado Contributes Additional Data on the Folsom Complex. Explordtions and Field-Work of the Smithsonian Institution in 1937, pp. 115-18. Washington.

Chaco Canyon Masonry. American Antiquity, Vol. 4, No. 1, pp. 60-1. Menasha.

The Aztecs. Southwestern Lore, Vol. 5, No. 1, pp. 1-6. Gunnison.

The Folsom Problem in American Archeology (revised and expanded). Annual Report of the Smithsonian Institution for 1938, pp. 531-46. Washington.

Archeological Remains in the Whitewater District, Eastern Arizona, Part I, House Types. Bureau of American Ethnology, Bulletin 121. Washington. 276 pp.
On the Trail of Ancient Hunters in the Western United States and Canada. Explorations and Field-Work of the Smithsonian Institution in 1938, pp. 103-10. Washington.

The Development of a Unit-Type Dwelling. In So Live the Works of Men, Seventieth Anniversary Volume Honoring Edgar Lee Hewett, edited by Donald B. Brand and Fred E. Harvey, pp. 311-23. University of New Mexico Press, Albuquerque.

Tree Rings and Cultures in the Southwestern United States. Nature, Vol. 144, Dec. 9, pp. 967-8. London.

\section{0}

Archeological Remains in the Whitewater District, Eastern Arizona, Part II, Artifacts and Burials, with appendix by T. D. Stewart on the Skeletal Remains from the Whitewater District, Eastern Arizona. Bureau of American Ethnology, Bulletin 126. Washington. $152 \mathrm{pp}$.

Excavations at the Lindenmeier Site Contribute New Information on the Folsom Complex. Explorations and Field-Work of the Smithsonian Institution in 1939, pp. 87-92. Washington.

Developments in the Problem of the North American Paleo-Indian. In "Essays in Historical Anthropology of North America Dedicated to John R. Swanton." Smithsonian Miscellaneous Collections, Vol. 100, pp. 51-116. Washington.

Pompeii Lives Again. The World is Yours, Vol. 1, No. 22. Columbia University Press, New York.

Pre-Pottery Horizon of the Anasazi and Mexico, In The Maya and Their Neighbors, pp. 331-40. D. Appleton-Century Co., Inc., New York.

\section{1}

Latest Excavations at the Lindenmeier Site Add to Information on the Folsom Complex. Explorations and Field-Work of the Smithsonian Institution in 1940, pp. 79-82. Washington.

\section{2}

Archeological and Geological Investigations in the San Jon District, Eastern New Mexico. Smithsonian Miscellaneous Collections, Vol. 103, No. 4, Publication No. 3692 . Washington. $30 \mathrm{pp}$.

Recent Evidence Relating to an Early Indian Occupation in North America. Proceedings of the Eighth American Scientific Congress, Vol. 2, pp. 31-8. Washington.

\section{3}

Egypt and the Suez Canal. Smithsonian Institution War Background Studies, No. 11. Washington. 68 pp.

Survival on Land and Sea. (Prepared for The United States Navy by the Ethnogeographic Board.) Publications Branch Office of Naval Intelligence, United States Navy.

Evidence for a Paleo-Indian in the New World. Acta Americana, Vol. I, No. 2, pp. 171-201. Mexico.

Edgar Billings Howard. American Anthropologist, Vol. 45, No. 3, pp. 453-4. Menasha.

A New Site. American Antiquity, Vol. 8, No. 3, p. 300. Menasha. (unsigned) 
1944

Antiquity of Man in Australia. The Scientific Monthly, Vol. 58, No. 2, pp. 156-7. Lancaster.

Etna Cave, Nevada. The Scientific Monthly, Vol. 59, No. 2, pp. 153-5. Lancaster.

Charles R. Scoggin, 1914-1944. American Antiquity, Vol. 10, No. 2, pp. 198-201. Menasha.

The New World Paleo-Indian. Annual Report of the Smithsonian Institution for 1944, pp. 403-33. Washington.

A Deep Burial on the Clear Fork of the Brazos River. Bulletin of the Texas Archeological and Paleontological Society, Vol. 16, pp. 9-30. Abilene.

Early Texans. Scientific Monthly, Vol. 60, pp. 392-3. Washington.

1946

One Hundred Years of Smithsonian Anthropology. Science, Vol. 4, No. 2693, pp. 119-25. Lancaster.

Prehistoric Peoples of Colorado. The Colorado Magazine, Vol. 23, No. 4, pp. 145-56. The State Historical Society of Colorado, Denver.

Prehistoric Peoples of Colorado. The Colorado Magazine, Vol. 23, No. 5, pp. 215-30, (a continuation of the July article). The State Historical Society of Colorado, Denver.

Carter's Thesis in the Light of Archeology: The Southwest. American Antiquity, Vol. 11, No. 4, pp. 266-9. Menasha.

\section{7}

The "Head Office" in the Smithsonian Institution and Cooperation with State and Local Institutions. In "Symposium on River Valley Archeology," American Antiquity, Vol. 12, No. 4, pp. 217-20. Menasha. 1948

Prehistoric Peoples. In Colorado and Its People, edited by LeRoy $R$. Hafen. Lewis Historical Publishing Company, Inc., New York.

A Crisis in U.S. Archeology. Scientific American, Vol. 179, No. 6, pp. 12-17. New York.

\section{9}

The Paleo-Indian in the Central Plains. In Proceedings of the Fifth Plains Conference for Archeology, Notebook No. 1, pp. 119-21. Laboratory of Anthropology, University of Nebraska. Lincoln.

\section{0}

The American Indian. In Exploring Our Prehistoric Indian Ruins, pp. 9-12. National Parks Association, Washington.

\section{1}

Radiocarbon Dates and Early Man. In "Radiocarbon Dating," assembled by Frederick Johnson, pp. 20-2. Memoirs of the Society for American Archaeology, No. 8. Salt Lake City.

The Early Americans. Scientific American, Vol. 184, No. 2, pp. 15-19. New York.

1952

River Basin Surveys: The First Five Years of the InterAgency Archeological and Paleontological Salvage Program. Annual Report of the Smithsonian Institution for 1951, pp. 351-83. Washington.

Carbon-14 Dates and Archeology. In "Symposium on the Measurement of Geologic Time." Transactions of the American Geophysical Union, Vol. 33, No. 2, pp. 170-4. Washington.
The Carbon-14 Method of Age Determination. Annual Report of the Smithsonian Institution for 1951, pp. 335-50. Washington.

The Inter-Agency Archeological Salvage Program: Results of Research in Various River Basins of the United States, Foreword. American Antiquity, Vol. 17 , No. 4, pp. 297-8. Menasha.

\section{3}

Recent Developments in the Early Man Problem in the New World. Eastern States Archeological Federation, Bulletin No. 12, pp. 9-11. Trenton.

Earliest Men in America: Their Arrival and Spread in Late Pleistocene and Post-Pleistocene Times, $\mathrm{Ca}$ hiers d'histoire mondiale (Journal of World History), Vol. I, No. 2, pp. 255-77. UNESCO (Commission Internationale pour une Histoire du Développement Scientifique et Cultural de l'Humanité), Paris.

\section{5}

The Inter-Agency Archeological and Paleontological Salvage Program in the United States. Pro Natura, Vol. 2, pp. 213-18. International Union for the Protection of Nature, Brussels.

The Inter-Agency Archeological and Paleontological Salvage Program. Missouri Archeological Society Newsletter, No. 96, pp. 7-10. Columbia.

1961

The River Basin Salvage Program after 15 Years. Annual Report of the Smithsonian Institution for 1960, pp. 523-49. Washington.

Status of the Salvage Program in the Missouri Basin. In Symposium on Salvage Archeology (Society for American Archaeology and the Committee for the Recovery of Archaeological Remains). Bloomington, Indiana, May 5-7, 1955, pp. 4-10. U.S. Department of the Interior, National Park Service, Washington.

The Agate Basin Complex. In Homenaje a Pablo Martinez del Rio en el XXV aniversario de la edición de Los Orígenes Americanos, pp. 125-32. Mexico.

\section{2}

The 1961 Excavations at Agate Basin, Wyoming. Plains Anthropologist, Vol. 7, No. 16, pp. 89-91. Lincoln.

Introduction to America's Buried Past, by Gordon C. Baldwin, pp. 11-14. G. P. Putnam's Sons, New York.

Comments on "The Paleo-Indian Tradition in Eastern North America," by Ronald J. Mason. Current Anthropology, Vol. 3, No. 3, pp. 262-3. Chicago.

\section{3}

Comment: Further Observations on Our Knowledge of Southwest Indian Civilization. In The New World Looks at Its History, pp. 21-4. Proceedings of the Second International Congress of the Historians of the United States and Mexico. University of Texas Press, Austin.

\section{4}

Antiquity and Origin of Man in North America. In Origins do Homen Americano, pp, 138-50. Instituto de Pré-Historia da Universidade de São Paulo Sob o Patrocinio da UNESCO, São Paulo.

SMITHSONIAN INSTITUTION

Washington, D.C.

August, 1966 